\title{
Infância e educação em Platão
}

Walter Omar Kohan

Universidade do Estado do Rio de J aneiro

\section{Resumo}

Este trabalho estuda, desde uma perspectiva filosófica, o conceito de infância em Platão, com ênfase nos seguintes diálogos: Alcibíades I, Górgias, A República e As Leis.

Num primeiro momento, situamos a questão da infância no marco mais ampliado do projeto filosófico e político de Platão. A seguir, propomos quatro traços principais do conceito de infância em Platão: a) como possibilidade (as crianças podem ser qualquer coisa no futuro); b) como inferioridade (as crianças como as mulheres, estrangeiros e escravos - são inferiores em relação ao homem adulto cidadão); c) como superfluidade (a infância não é necessária à pólis); d) como material da política (a utopia se constrói a partir da educação das crianças).

Não há a pretensão de levar Platão a algum tribunal. Busca-se apenas delimitar um problema e uma forma específica de enfrentálo, com vistas a contribuir para a análise da produtividade dessa perspectiva na história da filosofia da infância e da educação ocidental, bem como nas atuais teorias e práticas educacionais. Ao mesmo tempo, de forma implícita, procura-se oferecer elementos para problematizar uma visão já consolidada entre os historiadores da infância - particularmente desde o já clássico História social da infância e da família de Philippe Ariès -, segundo a qual a infância seria uma invenção moderna e ela não teria sido "pensada" pelos antigos enquanto tal.

\section{Palavras-chave}

Platão - Infância - Filosofia da infância.

\author{
Correspondência: \\ Walter Omar Kohan \\ Av. Sernambetiba, 4420, Bloco 12, \\ Apto. 302 \\ 22630-011 - Rio de J aneiro - RJ \\ e-mail: walterko@uol.com.br
}




\section{Childhood and educ ation in Plato}

Walter Omar Kohan

Universidade do Estado do Rio de J aneiro

\section{Abstract}

This work investigates from a philosophical perspective the concept of childhood in Plato, with an emphasis on the following dialogues: Alcibiades I, Gorgias, The Republic, and The Laws. Initially, we situate the issue of childhood within the wider scenario of Plato's political and philosophical project. We then propose four main features of the concept of childhood in Plato: a) as possibility (children can become anything in future); b) as inferiority (children - like women, foreigners and slaves - are inferior to the male adult citizen); c) as superfluousness (childhood is not necessary to the polis), and d) as matter of politics (the utopia is built from the education of children).

It has not been our intention here to put Plato on trial. We have just sought to delimit an issue and a specific manner of tackling it with the aim of contributing to the analysis of the productivity of this perspective in the history of the philosophy of childhood and of Western education, as well as of current education theories and practices. At the same time, we have implicitly tried to offer elements to problematize a vision well established among historians of childhood - particularly after Philippe Ariès already classic Centuries of childhood: a social history of family life - according to which childhood would be a modern invention and would not have been "thought" as such by the ancients.

\section{Keywords}

Plato - Childhood - Philosophy of childhood. 
Os filósofos gregos do período clássico deram, de forma quase unânime, importância singular à educação. Sabemos, por exemplo, que os sofistas foram educadores profissionais. Eles teorizaram sobre o sentido e 0 valor de educar, ainda que seus principais escritos não tenham chegado até nós (Platão, Hípias Maior 282b-c). Entre eles, Antifonte, que afirma, segundo um fragmento conservado, ser a educação o que há de principal para os seres humanos e que, quando se semeia em um corpo jovem uma nobre educação, esta floresce para sempre, com chuva ou sem chuva (DK 87 B 60).

Mesmo que declarasse não ter sido mestre de ninguém, Sócrates reconhece ter formado jovens que continuariam sua tarefa, e esse é justamente um dos motivos de sua condenação à morte (Platão, Apologia de Sócrates, 33a-c; 39c-d). 0 próprio Platão esteve preocupado, do princípio ao fim de seus diálogos com questões educacionais, talvez porque considerasse que a alma, quando vai para o Hades, não leva outra coisa senão sua educação e seu modo de vida (Fédon, 107d). Em sua última obra, As Leis, afirma que é impossível não falar da educação das crianças e que, diferentemente de outras questões tratadas em relação à pólis, o fará para instruir e para sugerir, não para legislar (VII, 788a): acerca da educação, diz ali, "O Ateniense", ser uma aporia legislar e ao mesmo tempo torna-se impossível permanecer em silêncio (788b-c).

Este texto trata de como nesses diálogos de Platão - nos que habitam traços do que hoje chamamos de filosofia da educação - foi demarcado um certo conceito de infância, proficuamente reproduzido e muito pouco problematizado no posterior desenvolvimento da filosofia da educação ocidental. À sua maneira, de forma explícita ou implícita, por meio de um discurso aporético e impossível de silenciar, com alusões diretas ou metafóricas, Platão deu forma a um retrato específico da infância. A seguir, nos ocuparemos de delinear esse retrato. ${ }^{1}$

\section{Os traços de um problema}

Giles Deleuze e Felix Guattari afirmam que entender um filósofo comporta compreender os problemas que esse filósofo traçou e os conceitos que criou para tentar resolver tais problemas (1993, p. 40). Pensamos que a infância era parte indissociável de um problema fundamental para Platão e que, por meio de seus diálogos, pode-se reconstituir tanto os traços fundamentais de tal problema quanto a solução conceitual proposta por Platão.

O problema ao qual aludimos é concreto e situado: entender, enfrentar e reverter a degradação da Atenas de seu tempo. Assim colocado, o problema não nos remete necessariamente à infância. Contudo, na visão de Platão, há uma conexão direta entre as qualidades de uma pólis e as dos indivíduos que a compõem, qualidades que não estão dadas de uma vez por todas mas que dependem fortemente do contexto em que se desenvolvem. Essa visão se apóia em uma percepção particular da história política que o precedeu e, durante a qual, naturezas juvenis excelsas, como as de seus companheiros de classe, Alcibíades e Crítias, se converteram em políticos inescrupulosos e insanos. As conseqüências foram desastrosas para Atenas e se poderia ler boa parte da filosofia de Platão como uma tentativa de colocar as bases que permitissem construir uma ordem social radicalmente diferente daquela que deu lugar, pelo menos num nível protagonista, à intervenção de tais cidadãos.

1. Para as referências bibliográficas das obras dos pensadores gregos, traduzimos os textos curtos diretamente do original. Para alguns diálogos de Platão utilizamos, como base, as traduções da Biblioteca Clássica Gredos (Madri: 1983-1992) nas quais introduzimos modificações. Citamos Antifonte pela edição canônica dos fragmentos estabelecida por $\mathrm{H}$. Dielz e W. Kranz em Die Fragmente der Vorsokratiker (Berlim, 1923), segundo a sigla DK, seguida do número atribuído nesta edição e o número do fragmento. No caso de Platão, citamos, como é habitual, pela edição de Stephanus. 0 número corresponde à página e a letra à coluna. Quando necessário, incluímos em romano o número do livro. Citamos os personagens dos diálogos de Platão entre aspas (por exemplo, "Sócrates"), para diferenciálos dos indivíduos históricos. 
Como enfrentar o problema da degradação dos jovens? 0 que fazer para canalizar as melhores naturezas para o melhor projeto político? A chave de interpretação de Platão para explicar o problema é educativa: esses jovens se corromperam porque não receberam a atenção e o cuidado que merece quem se dedicará a governar o conjunto. Sua aposta também o é: é necessário, então, pensar outro cuidado, outra criança, outra educação, uma experiência infantil da verdade e da justiça que preserve e cultive 0 que nessas naturezas há de melhor e 0 ponha a serviço do bem comum.

A visão platônica da infância se enquadra, então, em uma análise educativa com intencionalidades políticas. Platão não faz da infância um objeto de estudo em si mesmo relevante. De certo, a infância não é, enquanto infância, um problema filosófico relevante para Platão. Não há em seus diálogos uma particular atenção em retratar as características psicológicas da infância (contra, Charlot, 1977). A infância é um problema filosoficamente relevante na medida em que se tenha de educá-la de maneira específica para possibilitar que a pólis atual se aproxime o mais possível da idealizada. Dessa maneira, Platão inventa uma política (no sentido mais próximo de sua etimologia) da infância, situa a infância em uma problemática política e a inscreve no jogo político que dará lugar, em sua escrita, a uma pólis mais justa, mais bela, melhor.

Antes de analisar a forma em que Platão pensou a infância, é interessante expor algumas questões vindas da língua. Sabemos que a relação entre a história das palavras e a história do pensamento é extraordinariamente complexa, mas, em todo caso, não queremos deixar passar alguns esclarecimentos, pistas ou sugestões.

Platão se refere às crianças, basicamente, por meio de duas palavras: paîs e néos. ${ }^{2}$ Paîs remete a uma raiz indo-européia que toma a forma $p a / p o$ em grego e pa/pu em latim (a palavra latina equivalente a paîs é puer), cujo significado básico é "alimentar" ou "alimentarse". Da mesma raiz temática são, por exemplo, os termos patéomai ("comer"); ápastos ("sem comer", "em jejum", em latim impastus); patér ("pai", "o que alimenta", em latim pater); paízo (jogar como uma criança", "divertir-se", "fazer criancices"); póa ("pasto", em latim pasto); poimém ("pastor", "o que leva para comer", em latim pastor); paidíon ("jogo", "diversão"); paidiá ("jogo", "passatempo"); paideía ("cultura", "educação"); paidéúo ("formar", "educar"); paidagogós ("o que conduz a criança", "pedagogo") (Castello, A. ; Márcico, C., 1998).

Em grego clássico, paîs tem uma denotação muito ampla, refere-se a crianças e jovens de diversas idades, no caso dos meninos, até chegar à cidadania e, no caso das meninas, caso menos freqüente, até o matrimônio (Golden, 1990). Na verdade, paîs usase mais com o sentido de filho ou filha (natural ou adaptado) e menos com o sentido de crianças e, por extensão, como escravo ou escrava (jovens de diversas idades até limites semelhantes aos do paîs). Nesse sentido, seu uso é extremamente amplo (designa, por exemplo, o membro subordinado de um casal de homens homossexuais, não importa sua idade) e não implica uma reação emocional intensa entre os membros de uma família ou do mesmo grupo social (Golden, 1985). Essa mesma associação está presente no termo latino puer. Ainda que chamativa, essa ampliação pode ter como base um vínculo afetivo e cultural que relacionava o escravo com seu senhor, não totalmente dessemelhante, ao que vinculava o pai com seu filho (Castello, A. ; Márcico, C., 1998).

A outra palavra mais usada por Platão para designar a criança é néos, literalmente, "jovem", "recente", "que causa uma mudança", "novo". É uma palavra mais jovem ligada a uma raiz de significado temporal, nu, de onde vem, por exemplo, nûn, "agora" (Chantraine, P., 1975). Em usos antigos aplica-se não só às

2 . Há, pelo menos, uma terceira palavra para referir-se à criança em grego, téknon, ligada ao verbo tíkto ('dar a luz'), que marca mais acentuadamente a filiação, e nos trágicos se encontra usada para reforçar o vínculo afetivo, geralmente, a propósito da mãe. 
pessoas, mas a objetos e, mais raramente, a animais e plantas. Só posteriormente foi-se especializando em uma referência exclusivamente antropológica, mas conservando sua polivalência, que permite aplicá-la a crianças e jovens. Algumas palavras ligadas são: neótes ("juventude"); neoterízo ("tomar novas medidas", "fazer uma revolução"); neoterismós ("inovação", "revolução"). Nas línguas vernáculas, deu lugar a muitos compostos a partir do primeiro termo neo-.

Esses exemplos ilustram uma associação muito forte entre os campos semânticos do alimento e da educação no mundo greco-romano. Alimentar e educar não constituem, ali, domínios dissociados. Outros dois exemplos ilustram claramente essa associação. Em grego, tréphein significa, em sua origem, "espessar", e, daí, "coagular", "coalhar". Com esse sentido, subsiste na época clássica sob o conceito genérico de "criar", "nutrir", desenvolvido a partir de "engordar", "alimentar". Por graduais translações de sentido chega a significar "educar", ainda que nunca chegue a ser o termo típico para referir-se ao que hoje entendemos por educar e esteja mais ligado ao âmbito da criação das crianças. Por exemplo, Platão $(A$ República V 450c, Alcibíades I 122b, Críton 50e-51c) situa a trophé (criação) como um período intermédio entre o nascimento e a paidéia (educação). Em latim, tanto al.umnus ("o que recebe o alimento", "criatura" e, como segunda acepção, "discípulo", "o que apren$\mathrm{de}^{\prime \prime}$ ) como ad.ol.escens ("o que começa a ser alimentado", "o que recebe os primeiros alimentos" e, como conseqüência, "cresce") e ad.ul.tus têm a ver com 0 verbo al.o, "al.imentar-se" e o substantivo al.imentum, "al.imento".

Em grego clássico há outras palavras, algumas derivadas daquelas, para referir-se às crianças, mas não há nenhuma específica e exclusiva para alguma etapa ou idade em particular (Golden, 1990). Curiosa e significativamente, tampouco há, no mundo greco-romano, um substantivo abstrato derivado dessa raiz temática que signifique "infância". Em grego, a lógica da língua indicaria paidía ou paideía, mas daquele termo só se encontra algum raro exemplo (Chantraine, 1975) e este tem outra conotação, ligada também ao alimento ("cultura", "educação"). Em latim existe infantia, mas é bastante tardio e designa literalmente a ausência de fala. ${ }^{3}$

Como explicar essa ausência? Ainda que a infância fosse uma etapa da vida legal e politicamente irrelevante, há muitos testemunhos de vários campos intelectuais que distinguem diversas etapas na infância, o que permite supor que essas distinções tinham alguma relevância social (Golden, 1990). De qualquer modo, talvez a ausência de uma palavra para marcar uma etapa possa sugerir a percepção da vida humana, pelo menos na literatura dominante que conhecemos, como uma totalidade indissociável ou, talvez, uma unidade que privilegia o comum e o todo por sobre seus fragmentos ou partes diferenciadas.

Em todo caso, registramos duas marcas chamativas na etimologia. Por um lado, a associação entre "criança" e "escravo jovem". Por outro lado, a ausência de uma palavra específica para se referir à abstração "infância". Confiamos em que os sentidos dessa associação e dessa ausência possam ser enriquecidos no transcorrer deste texto.

Talvez não seja um detalhe que Platão, que se vale de palavras raríssimas e até inven-

3. Infans está formado por um prefixo privativo in e fari, 'falar', dali seu sentido de "que não fala", "incapaz de falar". Tão forte é seu sentido originário que Lucrécio emprega ainda o substantivo derivado infantia com o sentido de "incapacidade de falar". Mas logo infans - substantivado e infantia são empregados no sentido de "infante", "criança" e "infância", respectivamente. Desse sentido surgem vários derivados e compostos, na época imperial, como infantilis, "infantil" e infanticidium, "infanticídio". Quintiliano $(l, 1,18)$ fixa a idade em que a criança é considerada como incapaz de falar até por volta dos sete anos e, por isso, infans pode designar a criança no sentido ordinariamente reservado a puer. Na verdade, há usos de infans referindo-se a pessoas de até, pelo menos, quinze anos, com o qual devemos entender que infans não remete especificamente à criança pequena que não adquiriu ainda a capacidade de falar, mas que, antes refere-se aos que, por sua minoridade, não estão ainda habilitados para testemunhar nos tribunais: infans seria assim "o que não pode valer-se de sua palavra para dar testemunho". A palavra infantes também passa a designar a muitas outras classes de marginais que não participam da atividade pública, como os doentes mentais. 
tou muitas palavras para dar conta de conceitos ainda não pensados na cultura de seu tempo, não tenha tido a necessidade de fazer 0 mesmo com a infância. Contudo, como veremos a seguir, não parece justificado afirmar que a ausência de uma palavra específica signifique que Platão não tenha pensado a infância. Pelo contrário, de diversas formas compõe um certo conceito complexo, difuso, variado de infância. Para uma melhor análise, dividiremos esse tratamento em diversos planos que se entrecruzam: a) a primeira marca que distinguimos no conceito platônico de infância é a possibilidade quase total e, enquanto tal, a ausência de uma marca específica; a infância pode ser quase tudo; essa é a marca do sem marca, a presença de uma ausência; b) a segunda marca é a inferioridade em face do homem adulto, do cidadão, e sua conseqüente equiparação com outros grupos sociais, como as mulheres, os ébrios, os anciãos, os animais; essa é a marca do ser menos, do ser desvalorizado, hierarquicamente inferior; ${ }^{4} \mathrm{c}$ ) em uma terceira marca, ligada à anterior, a infância é a marca do não importante, o acessório, o supérfluo e do que se pode prescindir, portanto, o que merece ser excluído da pólis, o que não tem nela lugar, o outro depreciado; d) finalmente, a infância tem a marca instaurada pelo poder: ela é o material de sonhos políticos; sobre a infância recai um discurso de necessidade e o sentido de uma política que necessita da infância para erigir-se em perspectiva de um futuro melhor. A seguir, vamos nos referir a cada uma dessas marcas.

\section{A infância como pura possibilidade}

Platão não é alheio ao sentido mais primário da infância, que a associa a uma etapa primeira da vida humana. Como tal, a valoriza em função de seus efeitos na vida adulta. Fazendo-se eco de um ditado popular, "Crítias" afirma no Timeu (26b) que é admirável como permanecem na memória os conhecimentos aprendidos quando se é criança. Na Apologia, "Sócrates" disse temer muito mais àqueles acusadores que foram convencidos, quando eram crianças, de que ele era um sábio que se preocupava com as coisas celestes e subterrâneas e que fazia mais forte o argumento mais débil, do que àqueles que só foram convencidos daquelas acusações em idade adulta (Apologia de Sócrates 18b-c).

Não se trata de que, para Platão, a natureza humana se consolide e se torne imodificável a partir de certa idade. 0 discurso que Sócrates profere sobre o amor, no Banquete, e que havia sido ouvido de uma mulher, Diótima de Mantinéia, alerta que ainda que dissermos que as pessoas são as mesmas desde que nascem até morrerem, na verdade, se gera uma nova pessoa (ou uma criança) a cada momento (207d-e). "O Ateniense", em As Leis, diz que os jovens sofrem muitas mudanças todo o tempo, durante toda a sua vida (XI 929c).

Contudo, alguns momentos da vida são vistos como tendo mais incidência que outros, sobre o curso que ela toma. Também em As Leis, esse mesmo personagem lembra um refrão popular grego que diz "o começo é a metade de toda obra" (VI 753e) e afirma que um primeiro crescimento bom é o mais importante para uma boa natureza, tanto entre as plantas e entre os animais, como entre os humanos (Ibid. VI 765e). Em uma obra anterior, "Sócrates" diz a um jovem "Alcibíades" que, com 20 anos, está em idade de ocupar-se de si mesmo, porém, que isso seria muito difícil de fazer aos 50 anos (Alcibíades / 127e). Em outro diálogo, "Sócrates" se mostra preocupado com o jovem Clínias, temeroso de que, em função de sua idade, alguém se adiante e dirija sua alma para outros misteres (Eutidemo

4 . Quando nos referimos a adultos ou adultez, em Platão, deve-se entender o homem adulto, cidadão, nem escravo nem meteco. Não vamos tratar aqui, pela complexidade da questão, do problema destas e de outras figuras da ausência e da exclusão, como as mulheres 0 os anciãos. Para a exclusão das mulheres, cf. Cavarero, A. Nonostante Platone: figure femminili nella filosofia antica. Roma: Riuniti, 1990. 
275b). Em suma, ainda que Platão pense que a educação seja importante em toda a vida de um ser humano, também considera que o é muito mais nos momentos em que se forjam seus caracteres. Para explorar e justificar essa afirmação adentremos A República.

No livro I, "Sócrates" trava uma de suas clássicas discussões com vários interlocutores ("Céfalo", "Polemarco" e "Trasímaco") que são sucessivamente refutados em sua pretensão de definir o que é o justo. 0 final do livro I é aporético: "Sócrates" diz a Trasímaco que nada sabe após examinar, sucessivamente, se 0 justo é um mal e uma ignorância ou uma sabedoria e uma excelência e se a injustiça é mais vantajosa que a justiça (I 354b-c).

No começo do livro II, "Gláucon", irmão de Platão na vida real, convence "Sócrates" a retomar a discussão e defender a superioridade da justiça sobre a injustiça (II 357a - 358e). Depois que ele e "Adimanto", também irmão "real" de Platão, apresentam os argumentos correntes de quem defenderia que a injustiça é preferível à justiça, "Sócrates" transfere o campo da análise do indivíduo para a pólis, para facilitar a percepção da justiça em um espaço maior (II 368d-e).

A investigação leva "Sócrates" a analisar as origens da pólis: os indivíduos não são autárquicos e têm necessidade uns dos outros (369bc). Começa, então, um desenho da primeira pólis (369d-372e). Os traços iniciais de "Sócrates", relativos apenas às necessidades básicas de uma pólis, recebem uma objeção de "Gláucon": trata-se de uma pólis de suínos, já que não há nela nem prazeres nem comodidades (372e). Sem rodeios, "Sócrates" toma a objeção, passa a ampliar a pólis para uma pólis de prazer, mas adverte que, enquanto aquela é sã e verdadeira, esta é luxuosa e doente (372e-373a). Entre outras coisas, a nova pólis gerará guerras com os vizinhos e necessitará de guerreiros-guardiões, inexistentes na anterior (373d-374a). A partir de uma analogia com os cães de raça, "Sócrates" descreve as disposições naturais que devem ter tais guardiões: devem ser, enquanto corpo, agu- dos de percepção, rápidos e fortes; enquanto alma, irascíveis, suaves, amantes do saber e do aprender (374e-376c).

Haverá, então, que se criar e educar os guardiões de alguma maneira, diz "Sócrates" (376c - III 412b). Estamos diante de uma questão chave. A educação não é um problema menor, porque 0 exame da questão educacional poderá determinar a gênese, o ponto de partida, a causa da justiça e da injustiça na pólis (376c-d; IV 423e-424c). "Sócrates" propõe que a educação com a qual se eduquem os guardiões seja a mesma com a qual se educam, há muito tempo, os gregos: a ginástica para 0 corpo, a música para a alma (376e).

As crianças são educadas, em primeiro lugar, na música e, logo depois, na ginástica. Entre as primeiras atividades, inspiradas pelas Musas, incluem-se as fábulas e os relatos que as crianças escutam desde a mais tenra idade. Esses relatos deverão ser escolhidos com muita diligência, diz "Sócrates", para que contenham as opiniões que os construtores da pólis julgam convenientes para formar as crianças (377b-c).

Não se permitirá que as crianças escutem qualquer relato. Não se permitirá que se Ihes narrem, por exemplo, as principais fábulas pelas quais têm sido educados todos os gregos, os poemas de Homero e Hesíodo, uma vez que afirmam valores contrários àqueles que se pretende que dominem a nova pólis. Esses relatos, cheios de mentiras, não representam os deuses e heróis tal como são e estão povoados de personagens que afirmam valores contrários àqueles com que se pretende educar os guardiões (377c - III 392c).

De modo que, se se quer extirpar a injustiça da pólis, diz "Sócrates", ter-se-á de mudar os textos com os quais se tem educado sempre na Grécia. Antes de discutir quais relatos serão incluídos para substituir aos tradicionais, "Sócrates" afirma que se deverá ser extremamente cuidadoso na escolha dos textos com os quais as crianças entrarão em contato em primeiro lugar. Ele dá a seguinte razão: 
E bem sabes que o princípio de toda a obra é o principal, especialmente nos mais pequenos e ternos; porque é então quando se forma e imprime o tipo que alguém quer disseminar em cada pessoa. (II 377a-b)

Os primeiros momentos são os mais importantes na vida, diz "Sócrates". Por isso não se permitirá que as crianças escutem os relatos que contêm mentiras, opiniões e valores contrários aos que se espera deles no futuro. Porque se se pensa a vida como uma seqüência em desenvolvimento, como um devir progressivo, como um fruto que resultará das sementes plantadas, tudo o que venha depois dependerá desses primeiros passos. As marcas que se recebem na mais tenra idade são "imodificáveis e incorrigíveis" (378e). Por isso deve-se cuidar especificamente desses primeiros traços, por sua importância extraordinária para conduzir alguém para a virtude (ibidem).

Nesses traços platônicos está retratada a imagem da infância que ainda acompanha 0 pensamento educacional. É fundamental, diznos Platão, que nos ocupemos das crianças e de sua educação, não tanto pelo que os pequenos são, mas pelo que deles devirá, pelo que se gerará em um tempo posterior:

[Suficiente] é a educação e a criação, respondi; pois se bem educados, surgirão homens medidos que distinguirão claramente todas estas coisas e outras (...). (IV 423e)

Nesse registro, a infância é um degrau fundador na vida humana, a base sobre a qual se constituirá o resto. Como veremos, a educação da infância tem projeções políticas: uma boa educação garante um cidadão prudente. Esse primeiro degrau não tem características próprias muito definidas, está associado à possibilidade. É certo que há naturezas mais dispostas que outras para a virtude. Mas também é verdade que uma boa educação pode corrigir uma má nature- za e que uma educação inadequada faz estragos nas melhores naturezas.

Enquanto primeiro degrau da vida humana, a infância representa também seu caráter de incompleta, sua falta de acabamento. Porém, é verdade que, para Platão, a vida humana e 0 gênero humano como um todo estão marcados pela incompletude. A natureza dos seres humanos não está dada de uma vez por todas, mas vai se constituindo em função de certa educação que a transforma de geração em geração (IV 424a-b). A pólis que começa bem, diz Platão, avança da mesma forma que um círculo. Uma criação e uma educação valiosas produzem boas naturezas e, estas, valendo-se de tal educação, se tornam melhores que as anteriores e, assim, sucessivamente (ibidem).

A princípio, essa visão da infância parece extraordinariamente positiva, poderosa: dela pode devir quase qualquer coisa; dela, quase tudo pode ser. Contudo, essa potencialidade, esse ser potencial, esconde, como contrapartida, uma negatividade em ato, uma visão não afirmativa da infância. Ela poderá ser qualquer coisa. 0 futuro esconde um não ser nada no presente. Não se trata de que as crianças já são, em estado de latência ou virtualidade, o que irá devir; na verdade, elas não têm forma alguma, são completamente sem forma, maleáveis e, enquanto tais, podemos fazer delas o que quisermos.

Em uma passagem de As Leis, diferente em diversos aspectos da República, mas com temáticas afins, "O Ateniense" conta a "Clínias" uma história de dentes semeados e guerreiros nascidos deles e comenta sobre ela o seguinte:

(...) é, decerto, um grande exemplo para o legislador de que alguém pode persuadir as almas dos jovens daquilo que se proponha; de modo que o único que tem que descobrir em sua investigação é de que coisa deve-se persuadi-los para produzir o maior bem da pólis. (IV 423e) 
Podemos persuadir os jovenzinhos do que se nos ocorra. 0 único problema é descobrir o "maior bem" para a pólis para depois convencê-los de que atuem segundo ele. Os jovenzinhos não farão senão 0 que Ihes dissermos. Nessa passagem se condensam os principais motivos que destacaremos na última parte deste trabalho: temos que pensar nos jovens em função do bem da pólis, porque deles podem devir outra pólis que a atual, porque eles são o material de um sonho que podemos forjar à nossa vontade e que eles nos ajudarão, mansamente, a realizar. Antes, porém, vamos analisar outra marca da infância: a inferioridade.

\section{A infância como inferioridade}

J unto a essa visão da infância como 0 que pode ser quase tudo, nos textos de Platão há outra visão dela como aquela fase da vida inferior à idade adulta masculina tanto no aspecto físico quanto no espiritual. A obra em que esse relato aparece mais nítido, e também mais descarnado, é seu último texto, recémreferido, As Leis. Ali se afirma que as crianças são seres impetuosos, incapazes de ficarem quietos com o corpo e com a voz, sempre pulando e gritando na desordem, sem o ritmo e a harmonia próprios do homem adulto (II 664e-665a), e que possuem temperamento arrebatado (II 666a). As crianças sem seus preceptores são como os escravos sem seus donos, um rebanho que não pode subsistir sem seus pastores (VII 808d). Por isso, devem ser sempre conduzidas por um preceptor (VII 808e). Não devem ser deixadas livres até que seja cultivado "o que neles tem de melhor" (IX 590e-591a).

Também ali se afirma que a criança é a fera mais difícil de manejar, porque, por sua potencial inteligência ainda não canalizada, é astuta, áspera e insolente (VII 808d). Nessa passagem, além da inferioridade, aparece, outra vez, a idéia de potencialidade associada à criança, tal como vimos em A República. Nisto a criança se diferencia do escravo. Contudo, essa potencialidade não a torna melhor enquan- to projeta o que para Platão há de inferior no ser humano e na ordem social que 0 abriga: a desordem, a falta de harmonia, a desproporção.

"O Ateniense" estipula que uma criança, enquanto homem livre que será (no futuro), deve aprender diversos saberes e, enquanto escravo que é (no presente), pode e deve ser castigada por qualquer homem livre que se encontre com ela (VII 808e). Assim descrita a natureza infantil, com sua criação e educação buscar-se-á acalmar essa agitação e desenvolver seus potenciais em ordem e harmonia. A tarefa principal dos encarregados da criação das crianças é "dirigir em linha reta suas naturezas, sempre em direção para 0 bem segundo as leis". (II 809a)

Em um âmbito judicial, as crianças, como os escravos, só poderão dar testemunho em processos de assassinato e só no caso de um adulto responder por eventuais juízos contra ele por falso testemunho (XI 937b). Quando se trata de legislar seus direitos, Platão diz que se uma criança quer ser afastada da família por seu pai, terá direito a voz em um juízo com todos os seus parentes. Se a maior parte da família está de acordo em expulsá-la e nenhum outro cidadão quer adaptá-la, ela deverá, então, ser enviada para as colônias. Sustenta, também, que se algum ancião é considerado demente, se Ihe despojará todos os seus bens e este passará o resto de sua vida como se fosse uma criança (XI 929a-e).

A infância também aparece associada a outros estados inferiores, como quando serve de analogia para a embriaguez. Com efeito, Platão diz que quando alguém se embriaga desaparecem inteiramente suas sensações, suas lembranças, suas opiniões e seus pensamentos, e ele permanece com "a mesma disposição da alma de quando era uma criança pequena" (I 645e). Aqui aparece outra vez, nitidamente, a imagem da infância como ausência, vazio. Em estado de embriaguez, um adulto, como uma criança, carece de atividade sensorial e intelectual: é menos dono de si mesmo do que nunca, o mais pobrezinho de todos os homens. 0 embriagado é uma criança pela segunda vez, 
como o ancião (I 646a). Ao legislar sobre quem despoja os deuses, trai à pólis, ou corrompe suas leis, refere-se a quem poderia fazer essas ações como louco ou enfermo; trata-se de alguém ultrapassado em velhice ou "tomado pela infantilidade, 0 que em nada se diferencia dos estados anteriores" (IX 864d).

Esta visão da infância também está presente em um diálogo de juventude, o Alcibíades $I$, um texto que muitos filósofos da Antiguidade (Albino, Jâmblico, Proclo e Olimpiodoro) consideraram uma excelente introdução à filosofia em geral e à platônica em particular. 0 Alcibíades I pode ser dividido em três grandes seções: na primeira, "Sócrates" e "Alcibíades" discutem sobre a inserção deste último na vida política de Atenas e a respeito de seu saber sobre os assuntos da política (103a$113 \mathrm{c})$; na segunda, analisam as diferentes formas de se relacionar com o conhecimento e as implicações políticas de cada relação analisada (113d-127e); na terceira, propõe-se uma análise filosófica do preceito délfico "conhece-te a ti mesmo" (128a-135e).

No início, "Sócrates" questiona a "Alcibíades" que, desde criança, não duvidara sobre 0 justo e o injusto, mas que falara desses assuntos com segurança e presunção. "Acreditavas saber, apesar de ser criança, sobre o justo e o injusto", recrimina- 0 . "Como poderia sabêIo", "Sócrates" censura a "Alcibíades", "se não havia tido tempo de aprendê-lo ou descobrilo?" (110a-110c). Na infância não é possível saber sobre o justo e o injusto; é o tempo da incapacidade, das limitações no saber e, também, no tempo; é a etapa da falta de experiência; é a imagem da ausência do saber, do tempo e da vida.

Na parte intermediária do diálogo, "Sócrates" examina como a criação e educação dos persas e espartanos, rivais políticos, se diferencia da dos atenienses. 0 final desse exame marcará a necessidade de que Alcibíades conheça-se a si próprio - algo que não tinha feito ainda - enquanto suas possibilidades e limites. "Sócrates" argumenta para "Alcibíades" que se ele quer ter algum sucesso na vida política ele deve antes ocupar-se de si mesmo. ${ }^{5}$

"Sócrates" toma como exemplo os persas. A primeira diferença está ao nascer. Quando nasce um filho de um rei persa, toda a Ásia o festeja. Os atenienses, queixa-se "Sócrates", não comemoram os nascimentos, não lhes dão importância, não lhes oferecem a menor atenção. Quando nasce um ateniense, nem os vizinhos ficam sabendo (121c-d). ${ }^{5}$ Tampouco valorizam a criação (trophé) dos pequenos. Enquanto os persas disponibilizam os melhores eunucos e, aos 7 anos, põem os pequenos em contato com os cavalos e os levam à caça, os atenienses escolhem uma escrava de pouco valor para cuidar do recém-nascido (121d); aos 14 , os persas os confiam aos seus quatro melhores homens: o mais sábio, o mais justo, o mais prudente e o mais corajoso (121e). A um só tempo, o pedagogo de Alcibíades foi Zópiro, o mais inútil entre os escravos de Péricles (122b). No final das contas, entre os atenienses, a ninguém interessa 0 nascimento, a criação e a educação, salvo a um amante (ibidem).

Nessa passagem, a figura da infância é, como a vergonha, uma metáfora da inferioridade. A juventude de Alcibíades é uma das razões pelas quais a mãe do rei persa se surpreenderia ao tentar rivalizar-se com Ataxerxes (123c-e). Do

5 . Desse texto comentou Michel Foucault: "o cuidado de si aparece como uma condição pedagógica, ética e também ontológica, para chegar a ser um bom governante. Constituir-se em sujeito que governa implica que se tenha constituído em sujeito que se ocupa de si" (L'éthique du souci de soi comme pratique da liberté. In: Dits et Écrits, IV. Paris: Gallimard, 1994. p. 721-722).

6 . A queixa de "Sócrates" não pode ser tomada literalmente. M. Golden frisa que havia, entre os atenienses, ao menos um rito cerimonial para a aceitação social do recém-nascido. Celebrava-se entre cinco e sete dias depois do nascimento e incluía, pelo menos, um sacrifício, reunião familiar e decoração na porta da casa (coroa de oliveira para o menino; lã para a menina). As famílias mais pobres davam o nome ao recém-nascido nessa mesma cerimônia. As famílias das classes mais altas ofereciam, no décimo dia do nascimento, uma segunda cerimônia mais festiva e aberta a mais convidados para dar o nome ao pequeno (cf. Golden, 1990, p. 2324). Como interpretar a queixa de "Sócrates"? Talvez pelo peso relativo que estas cerimônias teriam em uma e outra sociedade ou, simplesmente, pelo caráter que as mesmas haviam adquirido em Atenas, caráter que provavelmente desagradava Sócrates por atender ao luxuoso, superficial e acessório e desatender ao principal. 
mesmo modo que Alcibíades sentiria vergonha perante a opulência dos persas, se sentiria uma criança diante da prudência, modéstia, destreza, benevolência, magnanimidade, disciplina, valor, constância, disposição, competitividade e honra dos espartanos (122c).

Em muitos outros diálogos, a infância ocupa um espaço semelhante de inferioridade. Na República, diz-se que as crianças, ao nascer, participam, sobretudo, do desejo; que algumas nunca participam da razão, da qual muitos participariam somente bastante mais tarde (IV 441a); nas crianças, como nas muIheres e escravos, domina o inferior: as paixões, os prazeres e as dores (IV 431c); crianças e mulheres admiram o matizado e 0 artificioso (VIII, 557c). No Teeteto, as crianças são alinhadas com as mulheres e as bestas como exemplos de indivíduos de uma classe que diferem entre si em sua relação com a saúde (171e). Em vários lugares e de diversas formas, Platão diz que as crianças não têm razão, compreensão ou juízo (Górgias 464de). Para referir-se a um argumento óbvio, simples ou sem importância, muitas vezes, afirma que é próprio de uma criança; nesses casos, o adjetivo "infantil" é sinônimo de pueril, ingênuo, débil (Críton 46d; Górgias, 470c, 471d; Banquete 204b). No Eutidemo, "Sócrates" diz algo que parece tão óbvio que "até uma criança o entenderia" e explica 0 assombro de "Clínias" ante esse saber por ser "jovem e ingênuo" (279e). No Lísis, "Ctésipo" ri de "Hipotales" porque este não é capaz de dizer à sua amante nada que uma criança não possa dizer (295c). No Filebo, os prazeres, como crianças, têm pouca inteligência (65d; cf. 14d). Diz-se de "Cármides" que era um caso excepcional, por não apresentar uma imagem negativa da criança (Cármides 154b).

Em outras ocasiões, "Sócrates" associa as crianças ao engano, a ser contraditório (dizer uma coisa e sua negação) ou ser inconsistente (dizer uma coisa e fazer outra). Por outro lado, sustenta que um pintor pode enganar as crianças como os tolos fazendo a aparência passar por verdade (A República X 598c). Outra vez, depois de mostrar a "Críton" que escapar da prisão suporia uma enorme inconsistência diante do que havia dito em sua vida, pergunta-Ihe se deveriam ignorar essa inconsistência e, assim fazendo, "em nada se diferenciariam das crianças" (Críton 49a-b). No Górgias, censura "Cálicles" por tratá-lo como uma criança ao dizer coisas com sentidos contrários $(499 b-c)$ e afirma que os oradores que tratam de agradar os cidadãos sem atender 0 interesse público, tratam- os como crianças (502e). No Teeteto, "Sócrates" afirma que na infância não temos conhecimento (197e); no Timeu, que nesse período não sabemos nada sobre a pólis nem sobre o passado (23b); e, no Eutidemo, Ihe parece incrível que "Dionisiodoro" e "Eutidemo" tenham conhecimentos desde crianças (294e). Em outro caso, usa a criança como a imagem de alguém temeroso ante a dor (Górgias 479a) e diante da morte (Fédon 77e). Também se afirma nos diálogos que a percepção das crianças é limitada: só percebem superfícies e não as profundidades (A República IX 577a).

Em suma, nos diferentes sentidos que constituem uma pessoa, em suas diversas capacidades físicas e intelectuais, Platão considera a criança inferior ao homem adulto, cidadão de Atenas. Não se trata de acusar Platão de insensível, adultocêntrico ou de violentar os direitos das crianças. Esse não parece um eixo de análise interessante. As realidades históricas são complexas demais para permitir juízos tão superficiais. Simplesmente, estamos querendo delinear o modo em que Platão pensou a idéia de infância, como contribuição para analisar a produtividade desse pensamento na história dos pensamentos filosóficos sobre a infância. Esse modo tem como parâmetro de medida um modelo antropológico de homem adulto, racional, forte, destemido, equilibrado, justo, belo, prudente, qualidades cuja ausência e estado embrionário, incipiente, torna as crianças e outros grupos sociais que compartilham dessa ausência, inferiores, na perspectiva de Platão. 


\section{A infância como o outro desprezado}

Sócrates conversa com jovens em muitos dos primeiros diálogos de Platão e afirma na Apologia que para ele é a mesma coisa conversar com pessoas de diversas idades (33a). Contudo, Platão não destinou nenhum lugar especial para o diálogo filosófico com jovens nos projetos educativos de $A$ República e de As Leis. Ao invés disso, em A República, propõe impedir que os jovens entrem em contato com a dialética (VII 536e-537a). Afirma que aos guardiões, desde a infância, devem ser ensinados cálculo, geometria e toda a educação propedêutica. Essa primeira educação da alma deve ser lúdica, espalhada entre os jogos e não forçada, já que nenhum saber permanece nela por força. Chegando aos 30 anos, escolher-seá alguns entre os mais aptos para colocá-los em contato com a dialética; antes se os impedirá pelos perigos dela: os jovens de Atenas costumam tomá-la como um jogo, levianamente, apenas para contradizer, sem crer em nada, desacreditando-se a si mesmos e à filosofia (VII 537e-539b; cf. Filebo 14d).

Esse descrédito pela filosofia está presente em outros diálogos de Platão. No Fédon, "Cebes" afirma que em Tebas, sua pólis, todos estariam de acordo que os filósofos mereciam a morte $(64 b-c)$. No Teeteto, "Sócrates" admite, referindo-se provavelmente a si mesmo, que os que se dedicam muito tempo à filosofia parecem oradores ridículos nos tribunais, comparados com quem habitualmente freqüenta esses espaços. Para falar dos filósofos, recorda uma anedota sobre Tales, que provocou o riso de uma jovem escrava (therapainis), ao cair num poço enquanto contemplava as estrelas. Desde então, essa piada acompanha os que se dedicam à filosofia (174ab). Na República, a má fama se diversifica e se agrava: "Adimanto" argumenta com "Sócrates" que quem não abandona a filosofia depois de abraçá-la para completar sua educação na juventude são, em sua maioria, pessoas estranhas (allokótuous) ou perversas; só os mais razoáveis entre eles são inúteis à pólis e este é o mal menor que os filósofos provocam (A República VI $487 c-d)$.

De todos, quem apresenta o argumento mais contundente contra a filosofia é "Cálicles" no Górgias, reafirmando essa associa-ção entre filosofia e infância afirmada por "Adimanto". "Cálicles" entra na conversa enfurecido pela forma que "Sócrates" tratou "Górgias" e "Polo", seus dois interlocutores anteriores. Ele pergunta a "Sócrates" se este fala sério ou se está brincando. "Sócrates" responde que ambos compartilham um mesmo afeto, porém, diferem com relação ao objeto desse afeto: enquanto ele ama a Alcibíades e à filosofia, Cálicles ama Demos e ao povo ateniense (ou seja, ele ama a retórica e a política, filodemia) (481c-d). "Cálicles" responde com a clássica contra-posição entre natureza (phýsis) e lei (nómos) (482e). Argumenta que "Sócrates" refutou seus interlocutores anteriores perguntado em um plano diferente do que eles respondiam. Segundo "Cálicles", "Polo" argumentava, por exemplo, que é pior sofrer injustiça do que cometê-la no plano da natureza e "Sócrates" - levava ao plano da lei, no qual acontece 0 contrário. A seguir, "Cálicles" faz uma apologia da natureza (na qual "o forte domina o fraco") e uma ácida crítica à lei ("obra dos fracos e da multidão"). Depois de sua apologia à natureza, ele diz:

Pois assim é a verdade, e o reconhecerás se, abandonando a filosofia, diriges tua atenção a coisas de maior importância. A filosofia, amigo Sócrates, é certamente uma ocupação grata, quando alguém se dedica a ela com medida nos anos juvenis, mas quando se atende a ela mais tempo do que o devido, é a corrupção dos homens. Porque ainda que se esteja bem dotado intelectualmente, quando se faz filosofia até a idade avançada, necessariamente seremos inexperientes em tudo aquilo que devemos conhecer bem, para ser alguém reputado e bem considerado. (Górgias 484c-d) 
A proximidade "natural" entre filosofia e infância se explica, nessa passagem, pela inadequação social de ambas: quando somos jovens podemos permitir essa diversão e dedicar-nos a coisas sem importância, mas se dedicamos toda a vida à filosofia seremos inexperientes (apeíron) para manejarmos os assuntos mais importantes, que são os assuntos da vida pública da pólis; desconheceremos as leis, não saberemos tratar os outros cidadãos, em público e no campo privado, não seremos, neste caso, esclarecidos nem bem considerados (émpeiron). É isso o que sucede a Sócrates. A filosofia, como a infância, está ligada à falta de experiência. 0 filósofo é tão ridículo e infantil nos assuntos públicos como os políticos o são nas conversas filosóficas (484d-e). "Cálicles" avança um pouco mais na comparação:

Está muito bem ocupar-se da filosofia na medida em que serve para a educação e não é feio filosofar enquanto se é jovem; mas quando se é velho, o fato torna-se vergonhoso, Sócrates, e eu não experimento a mesma impressão ante os que filosofam do que ante aos que falam mal e brincam. Com ef eito, quando vejo brincar e balbuciar uma criança, que por sua idade deve ainda falar assim, me causa alegria e me parece gracioso, próprio de um ser livre e adequado à sua idade. De modo contrário, quando escuto uma criança falar com clareza, parece-me algo desagradável, irrita-me o ouvido e o julgo próprio de um escravo. De outro lado, quando se ouve um homem falar mal ou 0 vemos brincando, fica ridículo, degradado e digno de açoites. Esta mesma impressão experimento também a respeito dos que filosofam. Certamente, vendo a filosofia em um jovem, tenho comprazer, me parece adequado e considero que este homem é um ser livre; pelo contrário, o que não filosofa me parece servil e incapaz de ser estimado, jamais digno de algo belo e generoso. Mas, por outro lado, quando vejo um homem de idade que ainda filosofa e que não renuncia a isto creio, Sócrates, que este homem deve ser açoitado. (485a-d)

De um lado a filosofia, a educação, 0 falar mal, o balbuciar, o brincar; de outro lado, o homem adulto, a política, o falar bem, o falar com clareza. Por natureza, a filosofia e a educação estão juntas e são próprias de uma idade tenra, como o falar mal, o balbuciar e 0 brincar. Para "Cálicles", o problema não está nem na filosofia, nem na infância, em termos absolutos. Pelo contrário, quando acontecem juntas em uma etapa da vida, são proveitosas: "está bem ocupar-se da filosofia na medida em que serve para a educação (paideías)", afirma "Cálicles". A filosofia vale como entretenimento e formação de algumas disposições. 0 problema, em sua opinião, é quando as coisas não respondem a seus tempos naturais. A liberdade ou a escravidão, a complacência ou os açoites, os risos ou a fúria de "Cálicles" virão da manutenção ou da quebra dessa linha divisória, de seguir a natureza ou de violentá-la. De modo que, para "Cálicles", a infância e a filosofia podem estar juntas porque ambas são, por natureza, coisas sem importância.

Platão responderá algumas poucas vezes a esse argumento com uma estratégia semelhante: no plano do que é, a filosofia é inútil, porque a pólis está sem rumo, perdida, desordenada, com os valores invertidos. No plano do que deve ser, os filósofos se ocupam do mais importante: 0 governo da pólis.

No Teeteto, "Sócrates" considera que mesmo que os filósofos pareçam inúteis, eles foram criados como homens livres. Os hábeis retóricos, por outro lado, como escravos: de almas pequenas e não retas, são servos do tempo e de seus discursos (172c-173b). Em uma citada passagem da República, "Sócrates" responde às objeções de "Adimanto" com a "Alegoria do Navio": no relato, quem maneja uma embarcação não tem nenhum conhecimento do ofício, todos ali comem e bebem até empanturrarem-se, se regem pelo prazer e não pelo saber: consideram inútil o "verdadeiro" piloto, que jul- 
ga ser necessário ter em conta as estações, 0 estado do tempo, o movimento dos astros e outras coisas tais para conduzir adequadamente a embarcação (488a-489a). Em um navio como este, afirma "Sócrates", os filósofos são certamente inúteis, mas não são responsáveis por isso, já que o natural seria que os homens que têm necessidade de governo fossem em busca de quem tem capacidade para fazê-lo (489b-c).

No Górgias, "Sócrates" responde dizendo que ele, o filósofo, é um dos poucos, se não o único, ateniense que se dedica à "verdadeira" arte da política (521d). 0 que se faz na pólis é sofística e retórica, não política. Tal qual o "verdadeiro" piloto do navio, em $A$ República, o verdadeiro político se preocupa com o bem e não com o prazer. "Sócrates" considera uma hipotética acusação e um eventual juízo contrário, na pólis, pela seguinte imagem:

Se me ocorre o mesmo que eu dizia a Polo, que serei julgado como o seria, diante de um tribunal de crianças, um médico acusado por um cozinheiro. Pensa, com ef eito, de que modo poderia defender-se o médico posto em tal situação: "Crianças, este homem Ihes causou muitos males; aos menores de vocês, ele os destroça cortando e queimando seus membros, e os faz sofrer enfraquecendo-os, sufocandoos; dá a vocês as bebidas mais amargas e os obriga a passar fome e sede; não como eu que os fartarei com toda a sorte de manjares agradáveis". 0 que crês que poderia dizer 0 médico posto neste perigo? Ou melhor, se dissesse a verdade: "Eu fazia tudo isso, crianças, por sua saúde". 0 quanto crê que protestariam tais juízes? Não gritariam com todas as suas forças? (Górgias 521e-522a)

Nesse caso, "Sócrates" compara os políticos a crianças que julgam o médico verdadeiro. Acusam-no de causar-Ihes muitos males. $\mathrm{Não}$ percebem que o médico de verdade cui- da da saúde de seus pacientes e não de seu prazer. Como tampouco os políticos de Atenas percebem que o verdadeiro político busca 0 bem e não o prazer. Nessa imagem do julgamento, as crianças ocupam o mesmo lugar que ocupavam os bêbados e os gulosos que tomavam o controle da embarcação na "alegoria do navio". São os que não têm domínio e nem controle sobre si.

Assim, "Sócrates" responde a "Cálicles" com sua mesma moeda: "as crianças são vocês". As crianças são sempre os outros. Esse talvez seja o único ponto em que "Sócrates" e "Cálicles" coincidem. Discordam sobre quase tudo: sobre a filosofia, sobre a política, a retórica, 0 bem, o prazer. Mas em uma coisa coincidem: "as crianças são vocês, os outros". As crianças são a figura do não desejado, de quem não aceita a própria verdade, da desqualificação do rival, de quem não compartilha uma forma de entender a filosofia, a política, a educação e, por isso, dever-se-á vencê-la. As crianças são, para "Sócrates" e para "Cálicles", portanto para Platão, uma figura do desprezo, do excluído, o que não merece entrar naquilo de mais valioso disputado por Platão, teoricamente, com os sofistas: a quem cor-responde o governo dos assuntos da pólis, tà politikà.

\section{A infância como material da polític a}

Tanto no Alcibíades I, quanto no Górgias, na República e nas Leis, as discussões que alcançam a infância e a educação adquirem sentido por sua significação política. No Alcibíades I a análise comparativa da educação de Alcibíades diante da educação dos rivais persas e espartanos permite avaliar as possibilidades de suas ambições políticas. No Górgias, depois de deixar desarticulados "Górgias", "Polo" e "Cálicles", "Sócrates" acaba o diálogo com um mito que reafirma que a questão inicial, "como se deve viver", deve ser respondida por uma chave política, em 
termos de se precaver de cometer injustiça, mais do que de padecê-la, e que o melhor modo de vida consiste em praticar e exortar os outros a praticar a justiça e todas as outras virtudes (527a-e). Na República, tantos cuidados na criação e educação dessas pequenas criaturas se justificam porque elas serão os futuros guardiões da pólis, seus governantes. Deve-se pensar nisso ao desenhar sua educação. Em As Leis, os legisladores se ocupam da educação no meio de uma pormenorizada análise que busca esgotar até os mínimos detalhes da vida na comunidade da pólis.

Voltemos à República. Como sabemos, essas crianças de cuja educação se preocupa Platão serão, no futuro, reis que filosofem e filósofos que governem, de modo justo, a pólis (V 473c-e). O legislador se preocupa, sobretudo, com sua criação (trophé), a etapa imediatamente posterior ao nascimento, por ser a mais trabalhosa de todas, e também com sua educação (V 450c). 0 princípio para organizar a vida entre os guardiões é proverbial: "comuns às coisas dos amigos" (IV 423e ss.; cf. V 450c ss). Entre eles, homens e mulheres, não haverá posses individuais de nenhuma ordem: nem materiais nem espirituais. Os bens, os companheiros e os filhos também seriam comuns (IV 421c ss.; cf. V 457d), caso se queira fomentar a maior unidade possível (que digam "é meu" e "não é meu" sobre o mesmo), cultivar o interesse de cada um pelo todo (o comum, a comunidade) por sobre suas partes (uma hipotética família ou propriedades individuais) e a um só tempo produzir governantes "dos mais excelsos" (V 459e).

A procriação entre os guardiões e a criação de suas crianças está rodeada de uma série de intrigas e mistérios justificados pelo legislador para manter e melhorar a "qualidade humana" da pólis (V 459c ss). Mentiras e enganos diversos, sorteios espúrios, festas orquestradas são planejados com a intenção de permitir mais procriações entre guardiões do que entre as classes "inferiores", sem que estas 0 saibam. Uma vez nascidos os pequenos, homens e mulheres, especialmente designados para isso, se ocuparão deles em uma casa especial, em um bairro específico da pólis, prévio ocultamento secreto dos que nascem com alguma deformidade (V 460c).

Ali, nos primeiros anos, as crianças serão indistintamente alimentadas pelas mães no período de amamentação, sem que se reconheçam seus filhos. Os jogos infantis serão regulamentados rigorosamente para que as crianças desenvolvam desde pequenas a estima e 0 apego pelas leis. A música e a ginástica serão praticadas segundo critérios igualmente estritos, cuidando para que não se introduza inovação nenhuma perante a ordem estabelecida pelos fundadores da pólis (IV 424b-e; cf. V 460c-d).

Encontramos nesse esquema os dois elementos básicos que definem uma clássica pedagogia formadora (Larrosa, 1996). Por um lado, educa-se para desenvolver certas disposições que existem em estado bruto, em potência, no sujeito a educar; por outro lado, educa-se para conformar, para dar forma, nesse sujeito, a um modelo prescritivo, que foi estabelecido previamente. A educação é entendida como tarefa moral, normativa, como o ajustar o que é a um dever ser. Na medida em que a normatividade que orienta a educação da $R e$ pública é um modelo de pólis justa, trata-se também ou, sobretudo, de uma normatividade e de uma tarefa políticas.

Segundo esse modelo, é alguém externo, um outro, o educador, o filósofo, o político, o legislador, o fundador da pólis, quem pensa e plasma para os indivíduos educáveis 0 que quer que estes sejam. É a idéia de educação como modelar a outro. Modelá-lo, formá-lo. Dar-Ihes uma forma. Qual forma? No caso de Platão é, em uma última instância, a forma das Formas; são as Idéias, os a priori, os modelos, os paradigmas, os em si transcendentes, entidades que são sempre do mesmo modo, indivisíveis, perfeitas, que indicarão a normatividade da formação. Assim formados, com a forma das Formas, com 0 conhecimento dessas realidades inteligíveis, as crianças chegarão a ser os filósofos que 
governarão adequadamente a pólis e, dessa maneira, nos permitirão conformar a pólis que desejamos produzir.

Nesse registro, as crianças não interessam pelo que são - crianças - mas porque serão os adultos que governarão a pólis no futuro. Nós, os adultos do presente, os fundadores da pólis, os que sabemos da ausência de certezas e os riscos desse chegar a ser, queremos o melhor para eles. Isto é, a uma só vez, o que nós consideramos melhor para nós, o que não pudemos ser, mas que queremos fazer que eles sejam. Tentaremos, ainda, acompanhá-los, ajudá-los nesse caminho. Para isso, nós os educaremos, desde a mais tenra idade. $\mathrm{E}$ o faremos com nossas melhores intenções. Nesse acompanhar os novos (hoi néoi) encontra sentido a educação formadora: na passagem de um mundo velho, que já não queremos, para um mundo novo - novo para nós, claro, velho para os novos -, que os outros trarão com nossa ajuda; ou que nós traremos com a ajuda deles.

Assim, a educação da República - como toda a educação formadora em sentido clássico
- não resiste à tentação de apropriar-se da novidade dos novos, à tentação de fazer da educação uma tarefa eminentemente política e da política o sentido final de uma educação, a partir de uma lógica da política determinada com independência da vontade dos novos. Educa-se para politizar os novos, para fazê-los participantes de uma pólis que se define previamente para eles. As relações entre política e educação são carnais: educa-se a serviço de uma política a um só tempo em que a ação política persegue, ela mesma, fins educativos. Por isso a educação é tão decisiva para Platão, porque é sua melhor ferramenta para alcançar a pólis sonhada.

Possibilidade, inferioridade, outro rechaçado, material da política. Marcas de uma filosofia da educação. Marcas sobre a infância deixadas por um pensamento. Marcas que situam a infância em uma encruzilhada entre a educação e a política. Primeiras marcas da infância na filosofia da educação. Antigas marcas da infância. Marcas distantes. Primeiras? Antigas? Distantes?

\section{Referências bibliográfic as}

CASTELLO, A.; MÁRCICO, C. Glosario etimológico de términos usuales en la praxis docente. Buenos Aires: 1998. Mimeografado. CHANTRAINE, P. Dictionnaire étymologique de la langue grecque. Paris: Klincksieck, 1975.

CHARLOT, B. L îdée d'enfance dans la philosophie de Platón. Revue de Métaphysique et de Morale, Paris, v. 82, n. 2, p. 232-245, avr-juin 1977.

DELEUZE, G.; GUATTARI, F. O que é a filosofia? São Paulo: Editora 34, 1993.

GOLDEN, M. Child and childhood in classical Athens. Baltimore: J ohn Hopkins University Press, 1990. . Pais, "child" and "slave". L'Antiquité Classique, Bruxelles, v. 54, 1985.

LARROSA, J. (Org.). La experiencia de la lectura. Barcelona: Laertes, 1996.

LIDDELL, H. G.; SCOTT, R. A greek english lexicon. ga ed. rev. Oxford: Oxford University Press, 1966.

Recebido em 15.10 .02

Aprovado em 18.03.02

Walter Omar Kohan é professor-titular de Filosofia da Educação da Faculdade de Educação da Universidade do Estado do Rio de J aneiro (UERJ ). Coordenador das séries: Filosofia na Escola (Editora Vozes) e Educação: Experiência e Sentido (Editora Autêntica). 